УДК 342.55

Д. С. Зарецкая

Иркутский государственный университет, г. Иркутск, Российская Федеращия

\title{
ПЕРЕРАСПРЕДЕЛЕНИЕ ПОЛНОМОЧИЙ ПРАВИТЕЛЬСТВ СУБЪЕКТОВ РОССИЙСКОЙ ФЕДЕРАЦИИ
}

\begin{abstract}
АНнОтАЦИЯ. Современный статус правительств субъектов РФ отражает общемировую тенденцию усиления исполнительной власти, причем не только центральную, но и в федеративных государствах на уровне исполнительной власти субъектов федерации. Помимо того, в федеративном государстве на статус правительств субъектов федерации огромное влияние оказывает правовое разграничение компетенции между уровнями исполнительной власти (центральной, региональной, местной), а впоследствии изменение компетенции, путем перераспределения полномочий правительств субъектов РФ. С течением времени, меняется законодательство РФ и появляются новые возможности перераспределения полномочий правительств субъектов РФ, в связи с чем, данный вопрос является всегда актуальным в аспекте правового статуса Правительств субъектов РФ. В статье рассматриваются основные подходы к перераспределению полномочий государственных органов, а также способы перераспределения полномочий, закрепленные в действующем федеральном законодательстве. Статья содержит примеры перераспределения полномочий на уровне субъектов РФ.
\end{abstract}

кЛючЕВЫЕ СЛОВА. Перераспределение; делегирование; разграничение; наделение; полномочия; правительства субъектов РФ.

ИНФОРМАЦИЯ О СТАТЬЕ. Дата поступления 9 ноября 2016 г.; дата принятия к печати 23 ноября 2016 г.; дата онлайн-размещения 30 ноября 2016 г.

D. S. Zaretskya Irkutsk State University, Irkutsk, Russian Federation

\section{REDISTRIBUTION OF GOVERNMENT POWERS OF THE RUSSIAN FEDERATION ENTITIES}

\begin{abstract}
The current status of the Russian Federation entity governments reflects the worldwide tendency of strengthening the executive power, whereby not only of the central one but also in the federative states at the executive power level of the federation entities. Besides, in the federative state the status of the entity governments of the federation is greatly affected by the legal differentiation of competence between the levels of the executive power (central, regional, local), and as a result of changing the competence, by redistributing the powers of the Russian Federation entity governments. In the course of time, the RF legislation changes and there appear new opportunities of redistributing the powers of the Russian Federation entity governments, for which reason this issue has always been topical in the context of the legal status of the Russian Federation entity governments.

KEYWORDS. Redistribution; delegating; differentiation; granting; powers; governments of the Russian Federation entities.

ARTICLE INFO. Received November 9, 2016; accepted November 23, 2016; available online November 30, 2016.
\end{abstract}

О перераспределении полномочий между органами власти можно говорить в двух аспектах - вертикальном (между правительством субъекта РФ и федеральными органами исполнительной власти; между правительством субъекта РФ и исполнительным органом муниципального образования), а также горизонтальном

(C) Д. С. Зареикая, 2016

\section{Baikal Research Journal}


(между органами власти одного уровня, в частности, между правительством и законодательным органом одного субъекта РФ, между правительством автономного округа и органом исполнительной власти субъекта, в состав которого входит автономный округ).

В науке конституционного права не сложилось единообразного подхода к определению понятия перераспределения полномочий. Нередко этот термин отождествляют с понятием «делегирование», что представляется неточным. Так, Г.Д. Садовникова пишет о перераспределении (взаимном делегировании) полномочий [1]. Л.Э. Гумашвили упоминает о делегировании (перераспределении) полномочий [2].

На наш взгляд, делегирование - более узкое понятие по сравнению с перераспределением. Ю.А. Тихомиров характеризует делегирование как один из способов перераспределения полномочий (наряду с централизацией, деконцентрацией и децентрализацией) [3]. При этом понятия «делегирование» и «наделение» как способы перераспределения полномочий в науке либо отождествляются [4], либо различаются [5]. Считается, что делегирование есть уполномочивание одним органом другого органа решить вопрос, отнесенный к компетенции первого органа [6], выполнять некоторые его полномочия [7]. В литературе обращается внимание на то, что не только ученые, но и законодатель неоднозначно использует терминологию в рассматриваемой сфере [Там же].

Перераспределение не совпадает с понятием «разграничение» полномочий, поскольку полномочия вначале разграничиваются и законодательно закрепляются, а в дальнейшем допускается перераспределение уже разграниченных полномочий. Неслучайно при определении разграничения полномочий употребляют такие термины, как установление (определение, закрепление) полномочий [8]. Таким образом, перераспределение полномочий выступает изменением компетенции, т.е. вторичным разграничением. При этом объем полномочий правительства субъекта РФ либо увеличивается (принимаются полномочия иного органа), либо уменьшается (полномочия передаются иному органу), но объем его правосубъектности не изменяется.

Следует отметить, что Конституционный Суд РФ в Определении Конституционного Суда РФ «Об отложении рассмотрения дела о проверке конституционности ряда положений Устава Тюменской области» от 17 июля 1996 г № 73-О назвал перераспределение одной из форм взаимодействия органов власти.

Необходимо подчеркнуть, что перераспределение полномочий в системе органов исполнительной власти должно быть направлено на децентрализацию управления, его совершенствование. Как справедливо в свое время писал М.А. Шафир, «такая передача должна носить исключительный характер, вызываться определенными условиями и быть научно обоснованной» [9].

Нормативной основой перераспределения полномочий правительства субъекта РФ является Конституция РФ и конституции (уставы) субъектов РФ, федеральные и региональные законы, а также договоры (соглашения).

Наиболее часто осуществляется перераспределение полномочий между правительством субъекта РФ и иными органами исполнительной власти - федеральными, местного самоуправления.

Перераспределение полномочий между правительством субъекта РФ и федеральными органами исполнительной власти предполагает делегирование исполнительно-распорядительных полномочий от власти одного уровня другому (от федерального уровня региональному и, наоборот, от уровня субъекта РФ на федеральный уровень).

Возможность перераспределения полномочий государственных органов исполнительной власти различного уровня обусловлена их тесной связью между

\section{Baikal Research Journal}


собой. Согласно ч. 2 ст. 77 Конституции РФ в пределах ведения Российской Федерации и полномочий Российской Федерации по предметам совместного ведения Российской Федерации и субъектов Российской Федерации федеральные органы исполнительной власти и органы исполнительной власти субъектов Российской Федерации образуют единую систему исполнительной власти в Российской Федерации. Соответствующие нормы есть и в основных законах субъектов РФ (ст. 75 Конституции Кабардино-Балкарской Республики, статья 66 Конституции Республики Коми, ч. 2 ст. 66 Устава (Основного Закона) Мурманской области, ч. 4 ст. 37 Устава (Основного закона) Ямало-Ненецкого автономного округа, ч. 5 ст. 38 Устава Нижегородской области, ч. 4 ст. 22 Устава Забайкальского края и т. д.).

Тесная связь элементов единой системы органов исполнительной власти выражается в возможности федеральных исполнительных органов и исполнительных органов субъектов федерации по взаимному соглашению делегировать друг другу часть своих полномочий. Хотя иногда в литературе можно встретить противопоставление передачи части полномочий и взаимодействия двух уровней власти между собой [10]. Выше приводилась позиция Конституционного Суда РФ о том, что перераспределение полномочий представляет собой одну из форм взаимодействия органов власти.

Части 2, 3 ст. 78 Конституции РФ закрепляют возможность перераспределения полномочий в системе органов исполнительной власти. При этом устанавливаются обязательные условия: договорный характер передачи осуществления полномочий; возможность передачи осуществления лишь части полномочий; соблюдение Конституции Российской Федерации и федеральных законов. Порядок реализации конституционной нормы определен в Федеральном законе «Об общих принципах организации законодательных (представительных) и исполнительных органов государственной власти субъектов Российской Федерации" от 6 июня 1999 г. № 184-Ф3, он предполагает заключение соглашений между органами власти двух уровней. При этом соглашения заключаются в случае, если осуществление части полномочий не может быть возложено федеральным законом в равной мере на исполнительные органы государственной власти субъекта РФ (ст. 26.8). Право заключения соглашений предусмотрено и в конституциях (уставах) субъектов РФ (ст. 22 Устава Воронежской области, ст. 54 Конституции Республики Дагестан, ч. 2 ст. 8 Конституции (Основного Закона) Республики Саха (Якутия), ст. 61 Конституции Республики Тыва, ч. 2 ст. 4 Конституции Республики Марий Эл и др.). Например, в соответствии с п. 7 ст. 103 Устава Красноярского края часть полномочий Правительства края может быть передана исполнительным органам государственной власти Российской Федерации на условиях и в порядке, которые предусмотрены Конституцией РФ, федеральными законами, Уставом и законами края, а также соглашениями с федеральными органами исполнительной власти, предусмотренными ст. 78 Конституции РФ.

Согласно Федеральному закону «Об общих принципах организации законодательных (представительных) и исполнительных органов государственной власти субъектов Российской Федерации» от 6 июня 1999 г. № 184-ФЗ федеральными законами, договорами о разграничении полномочий, соглашениями о передаче осуществления части полномочий между федеральными органами исполнительной власти и исполнительными органами государственной власти субъектов РФ, конституциями (уставами), законами и иными нормативными правовыми актами субъектов РФ не могут передаваться, исключаться или иным образом перераспределяться установленные Конституцией РФ предметы ведения РФ, предметы совместного ведения РФ и субъектов РФ, а также предметы ведения субъектов РФ. Кроме того, запрещается передача полномочий, ведущая к утрате установ-

\section{Baikal Research Journal}

электронный научный журнал Байкальского государственного университета 
ленных Конституцией РФ прав и свобод человека и гражданина, нарушению государственной целостности России и единства системы государственной власти. Вместе с тем в научных источниках встречалось мнение о допустимости уступки исключительных полномочий органов власти [11], возможности зайти сколь угодно далеко в передаче своих полномочий [12].

В ранее действующей редакции постановления Правительства РФ «О порядке подготовки, согласования и утверждения соглашений между федеральными органами исполнительной власти и исполнительными органами государственной власти субъектов Российской Федерации о передаче ими друг другу осуществления части своих полномочий, а также о внесении изменений в такие соглашения» от 1 марта 2004 г. № 117 (ред. от 9 июля 2004 г.) было отражено, что процедура заключения соглашений между правительством субъекта РФ и федеральными органами исполнительной власти определяется Правительством РФ. В 1994-1998 гг. 48 субъектов РФ инициировали заключение договоров о разграничении полномочий. Федеральные органы исполнительной власти заключали соглашения о разграничении полномочий с органами исполнительной власти субъектов РФ. На 1 января 2003 г. было заключено 290 таких соглашений [13]. При этом и договоры, и соглашения явно расходились с положениями федеральной Конституции.

Ситуация стала меняться с принятием в 1999 г. Федерального закона «О принципах и порядке разграничения предметов ведения и полномочий между органами государственной власти Российской Федерации и органами государственной власти субъектов Российской Федерации» от 24 июня 1999 г. № 119-ФЗ, а в дальнейшем - Федерального закона «О внесении изменений и дополнений в Федеральный закон “Об общих принципах организации законодательных (представительных) и исполнительных органов государственной власти субъектов Российской Федерации”» от 4 июля 2003 г. № 95-ФЗ. Законом предусмотрено, что соглашения заключаются в случае, если осуществление части полномочий не может быть возложено федеральным законом в равной мере на исполнительные органы государственной власти субъекта РФ. Таким образом, теперь правительству субъекта РФ необходимо доказать, что те или иные полномочия не могут относиться ко всем субъектам РФ, и как справедливо отмечают ученые, «сделать это иногда довольно трудно, поэтому легче вообще отказаться от заключения соглашений, даже когда они представляются выгодными для обеих сторон» [14].

В 2001 г. ряд субъектов РФ проявил инициативу расторжения договоров и соглашений о разграничении полномочий. За 2001-2002 гг. были подписаны 28 двусторонних (трехсторонних) документов о прекращении действия указанных договоров [15]. Более 50 соглашений утратили силу.

В настоящее время действует Постановление Правительства РФ «О порядке заключения и вступления в силу соглашений между федеральными органами исполнительной власти и исполнительными органами государственной власти субъектов Российской Федерации о передаче ими друг другу осуществления части своих полномочий» от 8 декабря 2008 г. № 924. Соглашения между правительством субъекта РФ и федеральными органами исполнительной власти могут заключаться на основании федерального закона или договора по предметам совместного ведения.

Кроме того, Постановлением Правительством РФ «Об утверждении Правил заключения соглашений между федеральным органом исполнительной власти и высшим исполнительным органом государственной власти субъекта Российской Федерации о предоставлении субсидий федеральному бюджету из бюджета субъекта Российской Федерации» от 13 октября 2008 г. № 752 утверждены Правила заключения соглашений между федеральным органом исполнительной власти и высшим исполнительным органом государственной власти субъекта РФ о пре-

\section{Baikal Research Journal}

электронный научный журнал Байкальского государственного университета 
доставлении субсидий федеральному бюджету из бюджета субъекта РФ. В соответствии с данными Правилами в соглашении должны указываться сведения о федеральном законе, устанавливающем расходное обязательство РФ, на исполнение которого предоставляется субсидия; целевое назначение субсидии; условия предоставления и расходования субсидии; объем бюджетных ассигнований; график перечисления субсидии; порядок осуществления контроля за расходованием субсидии; сроки и порядок представления отчетности о расходовании субсидии; порядок использования остатка субсидии, не использованной в текущем финансовом году. Проект соглашения подготавливается высшим органом исполнительной власти субъекта РФ и направляется федеральному органу исполнительной власти, который в свою очередь в 15-дневный срок присылает свои замечания и предложения по проекту. Копия подписанного соглашения представляется в Министерство регионального развития России.

В настоящее время соглашения о перераспределении полномочий с правительствами субъектов РФ заключают лишь некоторые федеральные органы исполнительной власти.

Так, Постановлением Правительства РФ от 10 декабря 2004 г. № 757 утверждено Соглашение между Федеральным дорожным агентством и Правительством Чеченской Республики о передаче Правительству Чеченской Республики осуществления части полномочий Федерального дорожного агентства по выполнению функций государственного заказчика Федеральной целевой программы «Восстановление экономики и социальной сферы Чеченской Республики (2002 год и последующие годы)». На основании Распоряжения Правительства РФ от 27 октября 2007 г. № 712 утверждены соглашения между Министерством РФ по делам гражданской обороны, чрезвычайным ситуациям и ликвидации последствий стихийных бедствий и правительством соответствующего субъекта РФ о передаче друг другу осуществления части своих полномочий.

В соответствии с Распоряжением Правительства РФ от 7 марта 2014 г. № 337-р заключены соглашения с Федеральной службой по надзору в сфере природопользования о передаче полномочий правительству субъекта РФ в области охраны окружающей среды в отношении субъектов хозяйственной и иной деятельности, зарегистрированных на территории субъекта и осуществляющих деятельность в границах его территории и оказывающих негативное воздействие на окружающую среду.

Распространены соглашения между Министерством внутренних дел РФ и правительствами субъектов РФ о передаче полномочия по рассмотрению предусмотренных отдельными статьями Кодекс об административных правонарушениях РФ дел об административных правонарушениях, совершенных на территории субъектов РФ, в частности, о несоблюдении требований, предписанных дорожными знаками или разметкой проезжей части дороги, запрещающими остановку или стоянку транспортных средств (например, Соглашение между Министерством внутренних дел Российской Федерации и Правительством Москвы о передаче городу Москве части федеральных полномочий по рассмотрению дел об административных правонарушениях, предусмотренных Кодексом Российской Федерации об административных правонарушениях, заключенное 1 ноября 2013 г.).

А.Ф. Ноздрачев полагает, что соглашения о делегировании федеральных полномочий органам исполнительной власти субъектов Федерации в любое время могут быть заменены административными актами, и практика их заключения может быть безболезненно прекращена [13]. В качестве обоснования своего мнения автор приводит примеры передачи федеральных полномочий правительствам субъектов РФ приказами федеральных органов: приказ Министерство экономического развития России «О передаче правительству Хабаровского края отдель-

\section{Baikal Research Journal}

электронный научный журнал Байкальского государственного университета 
ного полномочия по управлению портовой экономической зоной» от 20 февраля 2012 г., приказ Следственного комитета РФ «О передаче полномочий государственного заказчика на размещение заказов на поставки товаров, выполнение работ, оказание услуг для государственных нужд» от 30 сентября 2011 г. Думается, такая правовая форма перераспределения полномочий, без явно выраженного согласия правительства субъекта РФ, не соответствует положениям Конституции РФ и законодательства. Тем более что федеральные органы исполнительной власти нередко своими актами определяют порядок подготовки соглашений о передаче части своих полномочий правительствам субъектов РФ (Приказ Министерства экономического развития РФ «Об утверждении типовой формы соглашения с субъектом Российской Федерации о делегировании отдельных полномочий по управлению особой экономической зоной» от 21 января 2010 г. № 20, Приказ Министерства здравоохранения и социального развития РФ «О подготовке соглашений о передаче части полномочий по лицензированию фармацевтической деятельности органам исполнительной власти субъектов Российской Федерации» от 17 июля 2002 г. № 230).

Следует отметить, что федеральные органы исполнительной власти, передавшие осуществление части своих полномочий правительствам субъектов РФ, осуществляют контроль соблюдения условий соглашений и возлагают ответственность за ненадлежащее осуществление переданных полномочий.

Одним из контрольных механизмов является контроль за изданными по переданным полномочиям правовыми актами органов власти субъектов РФ. Так, на основании Постановления Правительства РФ «Об утверждении Правил отмены правовых актов органов исполнительной власти субъектов Российской Федерации, осуществляющих переданные полномочия Российской Федерации в области лесных отношений» от 29 июня 2011 г. № 524 Правительством РФ установлены основания и порядок отмены правовых актов органов исполнительной власти субъектов РФ, осуществляющих переданные полномочия РФ в области лесных отношений, в части, регулирующей осуществление переданных полномочий РФ в области лесных отношений.

В качестве примера должной формы регулирования перераспределения полномочий можно привести Федеральный закон «О федеральном бюджете на 2013 год и на плановый период 2014 и 2015 годов» от 3 декабря 2012 г. № 216-ФЗ: правительствам субъектов РФ передаются полномочия в области охраны и использования охотничьих ресурсов, водных, лесных отношений, охраны и использования охотничьих ресурсов по контролю, надзору, выдаче разрешений на добычу охотничьих ресурсов и заключению охотхозяйственных соглашений, охраны и использования объектов животного мира (за исключением охотничьих и водных биологических ресурсов).

Необходимо обратить внимание на то, что федеральные законы довольно часто неконкретно и неясно определяют полномочия органов субъектов РФ, нередко произвольно перераспределяют их, изменяют.

При перераспределении полномочий между правительством субъекта РФ и федеральными органами исполнительной власти необходимо учитывать, что правовые источники, регулирующие вопросы такого перераспределения, должны отвечать требованиям ясности, четкости и непротиворечивости, что предполагает, в частности, недопустимость закрепления за органами власти субъектов РФ неопределенных по своему объему и содержанию полномочий, притом что сами эти полномочия должны быть адекватными конституционному статусу субъектов федерации. Данная позиция отражена в Определении Конституционного Суда РФ «Об отказе в принятии к рассмотрению запроса Сахалинской областной Думы о

\section{Baikal Research Journal}


проверке конституционности подпункта «а» пункта 2 статьи 21 и подпункта 51.1 пункта 2 статьи 26.3 Федерального закона “Об общих принципах организации законодательных (представительных) и исполнительных органов государственной власти субъектов Российской Федерации”" от 17 июня 2008 г. № 452-О-О.

Кроме того, представляется целесообразным правительствам субъектов РФ передавать больше контрольных полномочий в области окружающей среды, землепользования, лесопользования, ветеринарии и др.

Формой перераспределения полномочий является предусмотренное ст. 26.9 Закона об органах субъектов РФ временное осуществление федеральными органами государственной власти отдельных полномочий органов государственной власти субъекта РФ. Такое перераспределение возможно в случаях, если:

- в связи со стихийным бедствием, катастрофой, иной чрезвычайной ситуацией органы государственной власти субъекта РФ отсутствуют и не могут быть сформированы в соответствии с Законом об органах субъектов РФ;

- возникшая вследствие решений, действий или бездействия органов государственной власти субъекта РФ просроченная задолженность субъекта РФ по исполнению долговых и (или) бюджетных обязательств, определенная в порядке, установленном Бюджетным кодексом РФ, превышает 30 \% собственных доходов бюджета субъекта РФ в последнем отчетном году;

- при реализации полномочий, осуществляемых за счет предоставления субвенций из федерального бюджета, исполнительным органом государственной власти субъекта РФ допускается нарушение Конституции РФ, федерального закона, нормативных правовых актов Президента РФ и Правительства РФ, если такое нарушение установлено соответствующим судом.

Решение о возложении соответствующих полномочий на федеральные органы государственной власти принимается Президентом РФ по согласованию с Советом Федерации.

Временное осуществление федеральными органами государственной власти отдельных полномочий органов государственной власти субъекта РФ не относится к мерам федерального вмешательства в отличие от чрезвычайного положения и военного положения. Меры временного осуществления полномочий органов государственной власти субъекта РФ федеральными органами государственной власти в Законе об органах субъектов РФ определены не в гл. V «Обеспечение законности в деятельности законодательного (представительного) органа государственной власти субъекта Российской Федерации, высшего должностного лица субъекта Российской Федерации (руководителя высшего исполнительного органа государственной власти субъекта Российской Федерации) и органов исполнительной власти субъекта Российской Федерации», которая посвящена ответственности соответствующих органов государственной власти субъекта РФ, а в гл. IV.I «Общие принципы разграничения полномочий между федеральными органами государственной власти и органами государственной власти субъекта Российской Федерации». Таким образом, временное осуществление федеральными органами государственной власти отдельных полномочий органов государственной власти субъекта РФ можно считать не санкцией конституционно-правовой ответственности [16-18], а мерой обеспечения нормального функционирования исполнительной власти субъекта РФ.

Перераспределение полномочий между правительством автономного округа и органом исполнительной власти субъекта, в состав которого входит автономный округ, осуществляется в соответствии с законодательством соответствующих субъектов РФ. При этом особое значение имеет принцип равноправия субъектов РФ (ч. 4 ст. 5 Конституции РФ). Все субъекты федерации независимо от типа

\section{Baikal Research Journal}

электронный научный журнал Байкальского государственного университета 
обладают равными правами во взаимоотношениях с федеральными органами государственной власти в государственно-правовой, бюджетной и других сферах. Кроме того, каждый из субъектов вступает в эти отношения непосредственно [19].

Перераспределение полномочий между органами субъектов РФ осуществляется на договорной основе, при этом договоры утверждаются законами субъектов.

Например, Законом Архангельской области «Об осуществлении органами государственной власти Архангельской области на территории Ненецкого автономного округа отдельных государственных полномочий органов государственной власти субъекта Российской Федерации по предметам ведения Российской Федерации и по предметам совместного ведения Российской Федерации и субъектов Российской Федерации» от 12 декабря 2007 г. № 467-23-О3 (в ред. от 19 декабря 2013 г.) определены особенности прохождения государственной гражданской службы государственными гражданскими служащими Архангельской области, осуществляющими государственные полномочия на территории Ненецкого автономного округа. Между органами власти данных субъектов РФ достигнута договоренность об осуществлении органами власти Архангельской области на территории Ненецкого автономного округа полномочий: по формированию и содержанию архивного фонда Ненецкого автономного округа; по организации и осуществлению региональных и межмуниципальных программ и проектов в сфере охраны окружающей среды и экологической безопасности, созданию и обеспечению охраны особо охраняемых природных территорий регионального значения, ведению Красной книги Ненецкого автономного округа, а также полномочий Российской Федерации в сфере охраны окружающей среды и в сфере водных отношений; по поддержке сельскохозяйственного производства; по организации и осуществлению региональных и межмуниципальных программ и проектов в сфере развития субъектов малого и среднего предпринимательства; по дорожной деятельности в отношении автомобильных дорог регионального или межмуниципального значения; по организации транспортного обслуживания населения автомобильным, водным, воздушным транспортом (пригородное и межмуниципальное сообщение); обеспечение образовательной деятельности на территории Ненецкого автономного округа осуществляется органами государственной власти Архангельской области в пределах своей компетенции; по организации оказания специализированной медицинской помощи в противотуберкулезном диспансере на территории Ненецкого автономного округа и др.

Между органами государственной власти указанных субъектов РФ также достигнута договоренность об осуществлении органами Ненецкого автономного округа на своей территории отдельных полномочий органов власти Архангельской области. В соответствии с Законом Архангельской области «Об утверждении Договора между органами государственной власти Архангельской области и Ненецкого автономного округа об осуществлении отдельных полномочий Архангельской области на территории Ненецкого автономного округа в сфере социальной поддержки и социального обслуживания граждан» от 19 декабря 2013 г. № 56-4-О3, в частности, органы государственной власти Архангельской области передают, а органы государственной власти Ненецкого автономного округа принимают на себя осуществление на территории округа полномочий по решению вопросов: социальной поддержки и социального обслуживания граждан пожилого возраста и инвалидов, граждан, находящихся в трудной жизненной ситуации, а также детей-сирот, безнадзорных детей, детей, оставшихся без попечения родителей, социальной поддержки ветеранов труда, лиц, проработавших в тылу в период Великой Отечественной войны 1941-1945 гг., семей, имеющих детей, жертв политических репрессий, малоимущих граждан, в том числе за счет предоставления субвен-

\section{Baikal Research Journal}


ций местным бюджетам для выплаты пособий на оплату проезда на общественном транспорте, иных социальных пособий, а также для возмещения расходов муниципальных образований в связи с предоставлением законами субъекта РФ льгот отдельным категориям граждан, в том числе льгот по оплате услуг связи, субсидий на оплату жилых помещений и коммунальных услуг; предоставления материальной и иной помощи для погребения. При этом органы государственной власти Архангельской области осуществляют финансовое обеспечение исполнения органами государственной власти Ненецкого автономного округа переданных полномочий в форме субвенции окружному бюджету из областного бюджета.

Понятно, что основная доля полномочий возлагается на правительства двух субъектов РФ.

Перераспределение полномочий между правительством и законодательным органом одного субъекта РФ не является распространенным явлением. В качестве примера разграничения полномочий (причем неясно, является ли оно первичным либо вторичным) между законодательными (представительными) и исполнительными органами государственной власти Архангельской области можно привести Закон Архангельской области «О разграничении полномочий между органами государственной власти Архангельской области в сфере энергосбережения и повышения энергетической эффективности» от 27 апреля 2011 г. № 276-21-О3 (в ред. от 17 ноября 2013 г.), в ст. 4 которого перечислены полномочия Правительства Архангельской области в рассматриваемой сфере.

Одним из наиболее важных направлений разграничения полномочий между правительством и законодательным органом субъекта РФ является нормотворчество. Законом об органах субъектов РФ полномочия в нормотворческой сфере закреплены за законодательным органом и исполнительным органом субъекта РФ в общих чертах. В ст. 5 , устанавливающей основные полномочия представительного органа, перечисляются вопросы, по которым принимаются законы. При этом перечень вопросов открыт: законом субъекта «регулируются иные вопросы, относящиеся в соответствии с Конституцией Российской Федерации, федеральными законами, конституцией (уставом) и законами субъекта Российской Федерации к ведению и полномочиям субъекта Российской Федерации». Конституции (уставы) субъектов РФ повторяют федеральную норму, не конкретизируя ее. Нормотворческие полномочия правительства субъектов формулируются весьма расплывчато. Также и в федеральных законах полномочия между законодательным органом и правительством субъекта РФ не разграничены, что нередко является причиной компетенционных споров в области нормотворчества. В частности, это характерно для Земельного кодекса РФ, Градостроительного кодекса РФ, Зћилищного кодекса РФ и многих других федеральных законодательных актов. Как справедливо отмечают ученые, такие формулировки в федеральных законах, как «устанавливается органами государственной власти субъектов Российской Федерации», "регулируется органами государственной власти субъектов Российской Федерации», «определяется органами государственной власти субъектов Российской Федерации», «законодательством субъектов Российской Федерации», «нормативными правовыми актами субъектов Российской Федерации», при отсутствии четкого разграничения полномочий органов государственной власти субъектов РФ по нормотворчеству вызывают только напряженность между представительным и исполнительным органами государственной власти субъектов РФ [20].

Необходимо отметить, что разрабатываемый более 15 лет Федеральный закон «О законах и иных нормативных правовых актах" до сих пор не принят. Вместе с тем во многих субъектах РФ соответствующие законы приняты. Иногда в них затрагиваются вопросы делегирования нормотворческих полномочий. Так,

\section{Baikal Research Journal}


Законом Республики Адыгея «О нормативных и иных правовых актах" от 9 октября 1998 г. № 92 (в ред. от 2 июня 2014 г.) предусмотрено, что делегирование нормотворческих полномочий может происходить внутри системы органов государственной власти Республики Адыгея. При этом в акте о делегировании должно быть указано, какое конкретное нормотворческое полномочие, какому органу и на какой срок делегируется. Орган, которому делегировано то или иное нормотворческое полномочие, не вправе его делегировать другому органу. Издавая нормативный правовой акт в порядке реализации делегированного полномочия, орган обязан сослаться на нормативный правовой акт, которым ему делегировано соответствующее полномочие. Схожая норма содержится и в Законе Республики Северная Осетия-Алания «О нормативных правовых актах Республики Северная Осетия-Алания» от 18 марта 2002 г. № 4-Р3 (ред. от 17 июля 2013 г.).

Очевидно, можно считать разновидностью перераспределения нормотворческих полномочий наделение правительства законом субъекта РФ полномочием по принятию конкретных подзаконных актов.

Перераспределение полномочий между правительством субъекта РФ и исполнительным органом муниципального образования связано с конституционно закрепленной возможностью наделения органов местного самоуправления отдельными государственными полномочиями. Согласно части 2 статьи 132 Конституции органы местного самоуправления могут наделяться законом отдельными государственными полномочиями с передачей необходимых для их осуществления материальных и финансовых средств [21]. Как правило, такое наделение осуществляется в рамках исполнительной власти по отдельным сферам общественных отношений законами субъектов РФ (например, Закон Тюменской области «О наделении органов местного самоуправления отдельными государственными полномочиями на 2013 год и на плановый период 2014 и 2015 годов» от 6 ноября 2012 г. № 90 (ред. от 2 декабря 2013 г.), Закон Ленинградской области «О наделении органов местного самоуправления муниципальных образований Ленинградской области отдельными государственными полномочиями Ленинградской области в сфере обращения с безнадзорными животными на территории Ленинградской области» от 10 июня 2014 г. № 38-оз, Закон Иркутской области «О наделении органов местного самоуправления областными государственными полномочиями по обеспечению детей-сирот и детей, оставшихся без попечения родителей, лиц из числа детей-сирот и детей, оставшихся без попечения родителей, жилыми помещениями по договорам социального найма в Иркутской области» от 29 июня 2010 г. № 52-ОЗ (ред. от 15 декабря 2011 г.), Закон Иркутской области «О наделении органов местного самоуправления отдельными областными государственными полномочиями в сфере труда» от 24 июля 2008 г. № 63-О3 (ред. от 11 декабря 2013 г.), Закон Иркутской области «О наделении органов местного самоуправления областным государственным полномочием по определению перечня должностных лиц органов местного самоуправления, уполномоченных составлять протоколы об административных правонарушениях, предусмотренных отдельными законами Иркутской области об административной ответственности» от 4 апреля 2014 г. № $37-03$ и др.).

Также законами субъектов РФ осуществляется изъятие переданных полномочий (например, Закон Ленинградской области «О прекращении осуществления органами местного самоуправления муниципальных образований Ленинградской области отдельного государственного полномочия Ленинградской области в сфере социальной защиты населения» от 17 марта 2014 г. № 10-оз).

Основные правила, касающиеся наделения органов местного самоуправления отдельными государственными полномочиями, закреплены в гл. 4 Федерального

\section{Baikal Research Journal}


закона «Об общих принципах организации местного самоуправления в Российской Федерации» от 6 октября 2003 г. (в ред. от 29 декабря 2014 г.) № 131-ФЗ.

Государственные полномочия могут быть переданы на определенный срок или бессрочно.

За правительством и определенными им органами исполнительной власти субъекта РФ остается контрольная функция за осуществлением органами местного самоуправления государственных полномочий. Например, постановлением Правительства Иркутской области «Об уполномоченном исполнительном органе государственной власти Иркутской области» от 10 июня 2014 г. № 279-пп контроль за осуществлением органами местного самоуправления полномочия в области производства и оборота этилового спирта, алкогольной и спиртосодержащей продукции возложен на службу потребительского рынка и лицензирования Иркутской области.

В настоящее время в соответствии с Федеральным законом «О внесении изменений в статью 26.3 Федерального закона “Об общих принципах организации законодательных (представительных) и исполнительных органов государственной власти субъектов Российской Федерации” и Федеральный закон “Об общих принципах организации местного самоуправления в Российской Федерации”» от 27 мая 2014 г. № 136-ФЗ (ред. от 23 июня 2014 г.) субъектам РФ предоставлено право своими законами перераспределять полномочия, которыми наделяются муниципальные образования. Часть полномочий могут быть взяты на уровень субъекта федерации.

Например, Законом Московской области «О перераспределении полномочий между органами местного самоуправления муниципальных образований Московской области и органами государственной власти Московской области» от 24 июля 2014 г. № 106/2014-ОЗ определено, что Правительство Московской области или уполномоченные им центральные исполнительные органы государственной власти осуществляют полномочия органов местного самоуправления городских поселений по подготовке и утверждению генерального плана городского поселения, а также по внесению в него изменений, подготовке и утверждению правил землепользования и застройки городских поселений, а также по внесению в них изменений и др. Правительство Московской области или уполномоченные им центральные исполнительные органы государственной власти осуществляют полномочия органов местного самоуправления муниципальных районов по выдаче разрешения на строительство, разрешения на ввод объектов в эксплуатацию при осуществлении строительства, реконструкции объектов капитального строительства, расположенных на территории сельских поселений. Органами государственной власти Московской области полномочия осуществляются за счет средств бюджета области на соответствующий финансовый год и на плановый период.

Согласно Закону Забайкальского края «О перераспределении между органами местного самоуправления и органами государственной власти Забайкальского края полномочий по решению вопроса местного значения - организации в границах поселений, муниципальных районов, городских округов электроснабжения населения» от 22 июля 2014 г. № 1014-33К с 1 января 2015 г. в ведение краевых органов власти переданы вопросы электроснабжения поселений, муниципальных районов и городских округов, ранее осуществляемые органами местного самоуправления.

Многие субъекты приняли законы, передающие на уровень правительств субъектов РФ полномочия по принятию решений по подготовке и утверждению схем территориального планирования муниципальных районов: по подготовке и утверждению генерального плана поселения, городского округа; по подготовке и

\section{Baikal Research Journal}

электронный научный журнал Байкальского государственного университета 
утверждению правил землепользования и застройки поселения, городского округа; принятию решений по подготовке и утверждению документации по планировке территории в поселении, городском округе на основании генеральных планов поселений, городских округов, а также по внесению в них изменений (например, Закон Удмуртской Республики «О перераспределении полномочий между органами местного самоуправления муниципальных образований и органами государственной власти Удмуртской Республики в сфере распоряжения земельными участками, государственная собственность на которые не разграничена, для строительства» от 19 сентября 2014 г. № 95-ОЗ).

Законами и законопроектами субъектов РФ в компетенцию правительств передаются полномочия в сфере дорожной деятельности, строительства, жилищно-коммунального хозяйства, здравоохранения, образования, культуры, спорта и по другим направлениям.

Таким образом, вопрос о перераспределении полномочий правительств субъектов Российской Федерации не является раз и навсегда решенным. С изменением социально-экономических условий, кадрового потенциала муниципальных образований должно осуществляться перераспределение полномочий с целью эффективного управления.

\section{Список использованной литературы}

1. Садовникова Г. Д. Комментарий к Конституции Российской Федерации (постатейный) / Г. Д. Садовникова. - 3-е изд., испр. и доп. - М. : Юрайт-Издат, 2006. - 188 с.

2. Гумашвили Л. Э. К вопросу о методологических аспектах определения собственных предметов ведения Чеченской Республики / Л. Э. Гумашвили // Государственная власть и местное самоуправление. - 2011. - № 9. - С. 6-9.

3. Тихомиров Ю. А. Теория компетенции / Ю. А. Тихомиров // Зћурнал российского права. - 2000. - № 10. - С. 22-32.

4. Костикова Г. В. Некоторые вопросы совершенствования реализации органами местного самоуправления отдельных государственных полномочий / Г. В. Костикова // Российская юстиция. - 2010. - № 2. - С. 19-22.

5. Игнатюк Н. А. Спровоцированное изменение законодательства о полномочиях органов исполнительной власти в РФ / Н. А. Игнатюк // Федерализм. - 2005. - № 2. - С. 98-99.

6. Лазарев Б. М. Компетенция органов управления / Б. М. Лазарев. - М. : Юрид. лит., 1972. $-280 \mathrm{c.}$

7. Тихомиров Ю. А. Административное право и процесс: полный курс / Ю. А. Тихомиров. - М. : Юринформцентр, 2001. - 652 с.

8. Черепанов В. Разграничивать или делегировать? / В. Черепанов // Сравнительное конституционное обозрение. - 2007. - № 1. - С. 163-167.

9. Шафир М. А. Компетенция СССР и союзной республики / М. А. Шафир. - М. : Наука, 1968. - 228 с.

10. Тихомирова Л. А. Роль соглашений в разграничительном процессе Российской Федерации и ее субъектов / Л. А. Тихомирова // Российская юстиция. — 2010. — № 7. С. $12-15$.

11. Конституция Российской Федерации : энцикл. словарь / В. А. Туманов, В. Е. Чиркин, Ю. А. Юдин [и др.]. - М. : Больш. рос. энцикл. : Юристъ,1995. - 320 с.

12. Абдулатипов Р. Г. Опыты федерализма / Р. Г. Абдулатипов, Л. Ф. Болтенкова. М. : Республика, 1994. - 318 с.

13. Ноздрачев А. Ф. Административные соглашения (теоретическое рассмотрение проблемы и анализ практики использования в государственном управлении) / А. Ф. Ноздрачев // Законодательство и экономика. - 2012. - № 9. - С. 5-31 ; № 10. - С. 17-34.

14. Андриченко Л. В. Конституционные основы российского федерализма / Л. В. Андриченко, Е. А. Юртаева // Журнал российского права. - 2013. - № 6. - С. 5-16.

15. Демидов М. В. Место и роль Федеративного и иных договоров о разграничении предметов ведения полномочий в системе федеративных отношений в России / М. В. Демидов // Конституционное и муниципальное право. - 2013. - № 3. - С. 28-33.

\section{Baikal Research Journal}


16. Безруков А. В. Совершенствование законодательного регулирования института конституционной ответственности субъектов Российской Федерации / А. В. Безруков, А. А. Кондрашев // Государство и право. - 2004. - № 8. - С. 39-49.

17. Котелевский Д. В. Институт федерального вмешательства в конституционном праве Российской Федерации : автореф. дис. ... канд. юрид. наук : 12.00 .02 / Д. В. Котелевский. - Екатеринбург, 2002. - 26 с.

18. Собянин С. С. Основные способы федерального вмешательства: мировой опыт и российская практика / С. С. Собянин // Государственное и муниципальное право. - 2006. № 11 . - C. 2-8.

19. Постатейный комментарий к Конституции Российской Федерации / под общ. ред. В. Д. Карповича. - М. : Юрайт-М : Нов. Правов. культура, 2002. - 959 с.

20. Ларионов В. П. О разграничении нормотворческих полномочий законодательного и исполнительного органов государственной власти субъектов Российской Федерации / В. П. Ларионов, Н. П. Петров // Спорт: экономика, право, управление / гл. ред. С. И. Нагих. - М. : Юрист, 2008. - Вып. 4. - С. 21-23.

21. Кузнецова Н. В. Делегирование полномочий в сфере взаимодействия органов государственной власти и местного самоуправления в Российской Федерации : дис. ... канд. юрид. наук : 12.00.02 / Н. В. Кузнецова. - М., 2005. - 180 с.

\section{References}

1. Sadovnikova G. D. Kommentarii k Konstitutsii Rossiiskoi Federatsii (postateinyi) [Commentary to the Constitution of the Russian Federation (clause-by-clause). $3^{\text {rd }}$ ed. Moscow, Yurait Publ., 2006. 188 p.

2. Gumashvili L. E. On issue of methodological aspects of determining own authority matters in Chechen Republic. Gosudarstvennaya vlast' $i$ mestnoe samoupravlenie = State Power and Local Self-government, 2011, no. 9, pp. 6-9. (In Russian).

3. Tikhomirov Yu. A. Theory of competence. Zhurnal rossiyskogo prava = Journal of Russian Law, 2000, no. 10, pp. 22-32. (In Russian).

4. Kostikova G. V. Some issues of improving implementation of separate governmental powers by local governments. Rossiiskaya yustitsiy = Russian Justice, 2010, no. 2, pp. 19-22. (In Russian).

5. Ignatyuk N. A. Proved changes legislation on powers of executive authority bodies in the Russian Federation. Federalism, 2005, no. 2, pp. 98-99. (In Russian).

6. Lazarev B. M. Kompetentsiya organov upravleniya [Competence of management bodies]. Moscow, Yuridicheskaya Literature Publ., 1972. $280 \mathrm{p}$.

7. Tikhomirov Yu. A. Administrativnoe pravo i protsess. Polnyi kurs [Administrative Law and Process. A Complete Course]. Moscow, Yurinformtsentr Publ., 2001. 652 p.

8. Cherepanov V. To differentiate or delegate? Sravnitel'noe konstitutsionnoe obozrenie = Comparative Constitutional Review, 2007, no. 1, pp. 163-167. (In Russian).

9. Shafir M. A. Kompetentsiya SSSR $i$ soyuznoi respubliki [Competence of the USSR and union republics]. Moscow, Nauka Publ., 1968. 228 p.

10. Tikhomirova L. A. Role of contracts in differential process of Russian Federation and its entities. Rossiiskaya yustitsiy = Russian Justice, 2010, no. 7, pp. 12-15. (In Russian).

11. Tumanov V. A., Chirkin V. E., Yudin Yu. A. et al. Konstitutsiya Rossiiskoi Federatsii. Entsiklopedicheskii slovar' [Constitution of the Russian Federation. Encyclopedic Dictionary]. Moscow, Bol'shaya Rossiiskaya entsiklopediya Publ., Yurist Publ.,1995. 320 p.

12. Abdulatipov R. G., Boltenkova L. F. Opyty federalizma [Experience of federalism]. Moscow, Respublika Publ., 1994. 318 p.

13. Nozdrachev A. F. Administrative contracts (theoretical consideration of problems and analysis of application practice in governmental management) Zakonodatel'stvo i ekonomika= Legislation and Economics, 2012, no. 9, pp. 5-31; no. 10, pp. 17-34. (In Russian).

14. Andrichenko L. V., Yurtayeva E. A. Constitutional basics of Russian federalism. Zhurnal rossiyskogo prava = Journal of Russian Law, 2013, no. 6, pp. 5-16. (In Russian).

15. Demidov M. V. Place and role of Federal and other contracts on differentiation authorization maintenance subjects in Russia's system of federal relations. Konstitutsionnoe $i$ mu nitsipalnoe pravo = Constitutional and Municipal Law, 2013, no. 3, pp. 28-33. (In Russian).

\section{Baikal Research Journal}


16. Bezrukov A. V., Kondrashev A. A. Improvement in adjustment of constitutional responsibility of subjects of Russian Federation. Gosudarstvo i pravo = State and Law, 2004, no. 8, pp. 39-49. (In Russian).

17. Kotelevsky D. V. Institut federal'nogo vmeshatel'stva $v$ konstitutsionnom prave Rossiiskoi Federatsii. Avtoref. Kand. Diss. [Institute of federal interference in the constitutional law of the Russian Federation. Cand. Diss. Thesis]. Yekaterinburg, 2002. 26 p.

18. Sobyanin S. S. Main ways of federal interference: world experience and Russian practice. Konstitutsionnoe i munitsipalnoe pravo = Constitutional and Municipal Law, 2006, no. 11, pp. 2-8. (In Russian).

19. Karpovich V. D. (ed.). Postateinyi kommentarii $k$ Konstitutsii Rossiiskoi Federatsii [Cause-by-clause commentary of the Constitution of the Russian Federation]. Moscow, Yurait-M Publ., Novaya Pravovaya kul'tura Publ., 2002. 959 p.

20. Larionov V. P., Petrov N. P. On differentiation of norm-setting powers of legal and executive bodies of the governmental authority bodies of the Russian Federation entities. In Nagikh S. I. (ed.). Sport: ekonomika, pravo, upravlenie [Sport: Economy, law, management]. Moscow, Yurist Publ., 2008, iss. 4, pp. 21-23. (In Russian).

21. Kuznetsova N. V. Delegirovanie polnomochii $v$ sfere vzaimodeistviya organov gosudarstvennoi vlasti $i$ mestnogo samoupravleniya $v$ Rossiiskoi Federatsii. Kand. Diss. [Delegating powers in the sphere of interaction of governmental authority bodies and local governments in the Russian Federation. Cand. Diss.]. Moscow, 2005. 180 p.

\section{Информация об авторе}

Зареикая Дарья Сергеевна - аспирант, кафедра конституционного права и теории права, Юридический институт, Иркутский государственный университет, 664082, г. Иркутск, ул. Улан-Баторская, 10, e-mail: zareckaya@irzs.ru.

\section{Author}

Darya V. Zaretskaya - PhD Student, Chair of Constitutional Law and Theory of Law, Law Institute, Irkutsk State University, 10 Ulan-Bator St., 664082, Irkutsk, Russian Federation; e-mail: zareckaya@irzs.ru.

\section{Библиографическое описание статьи}

Зарецкая Д. С. Перераспределение полномочий правительств субъектов Российской Федерации / Д. С. Зарецкая // Baikal Research Journal. - 2016. - Т. 7, № 6. - DOI: 10.17150/2411-6262.2016.7(6).23.

\section{Reference to article}

Zaretskya D. S. Redistribution of government powers of the Russian Federation entities. Baikal Research Journal, 2016, vol. 7, no. 6. DOI: 10.17150/2411-6262.2016.7(6).23. (In Russian).

\section{Baikal Research Journal}

